\title{
Using systematic screening to integrate health services in India and Senegal: Pilot study versus scale-up results
}

James R. Foreit

Population Council

Follow this and additional works at: https://knowledgecommons.popcouncil.org/departments_sbsr-rh

Part of the Demography, Population, and Ecology Commons, Family, Life Course, and Society Commons, International Public Health Commons, and the Medicine and Health Commons How does access to this work benefit you? Let us know!

\section{Recommended Citation}

Foreit, James R. 2008. "Using systematic screening to integrate health services in India and Senegal: Pilot study versus scale-up results," FRONTIERS Final Report. Washington, DC: Population Council. 


\title{
Using Systematic Screening to Integrate Health Services in India and Senegal: Pilot Study versus Scale-up Results
}

\author{
Frontiers in Reproductive Health, Population Council \\ James Foreit
}

October 2008

This study/publication is made possible by the generous support of the American people through the United States Agency for International Development (USAID) under the terms of Cooperative Agreement No. HRN-A-00-98-00012-00. The contents are the responsibility of the FRONTIERS Program and do not necessarily reflect the views of USAID or the United States Government.

\section{(2) Population Council FRONTIERS}

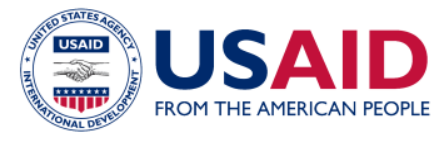


(C) 2008 The Population Council, Inc.

Suggested citation: Foreit, James. 2008. "Using systematic screening to integrate health services in India and Senegal: Pilot study versus scale-up results," FRONTIERS Final Report. Washington, DC: Population Council.

Any part of this publication may be reproduced without permission for limited distribution provided it is distributed without charge and the Population Council is acknowledged as the source. The Population Council would appreciate receiving a copy of any materials in which the text is used. 


\section{Contents}

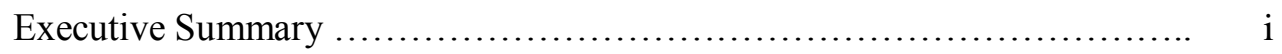

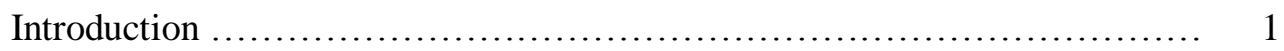

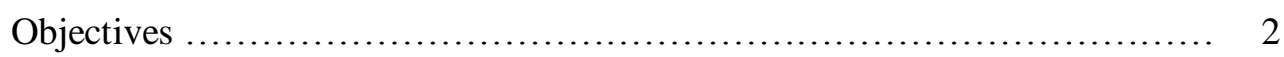

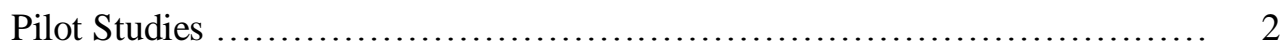

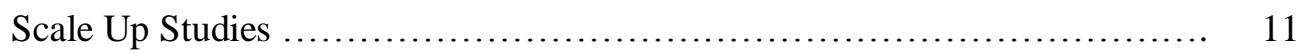

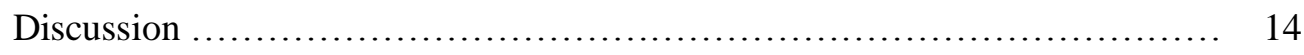

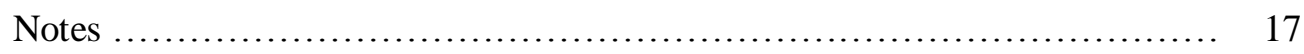

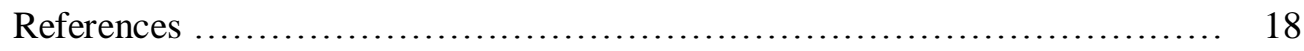

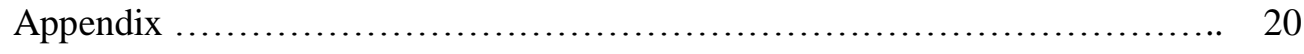




\section{Executive Summary}

Relatively small-scale experiments were undertaken to determine if systematic screening for unmet needs for health services could increase the number of preventive care services clients receive at health care visits in India, Senegal, Bolivia, and Honduras. Studies in Honduras and Bolivia were not completely implemented, whereas the experiments were successfully completed in Senegal and India, and health authorities in both countries consequently scaled-up systematic screening. Since little is known what happens when an intervention is scaled up from pilot to program levels, FRONTIERS participated in the scale-up to test the effect of different supervision and training strategies on frequency of provider screening.

The India pilot study used a randomized control design while the Senegal pilot used a simple before and after design. The independent variable in both studies was the use of a screening form by providers. Dependent variables included number of services provided per client visit, scheduled appointments per client visit, and referrals to other facilities per client visit. In India the study was conducted in the city of Vadodara; in Senegal, the study was conducted in both urban and rural health posts. The Bolivia and Honduras studies were both pre-test, post-test pilots.

After completion of the pilot in India, systematic screening was scaled up to 63 facilities in three districts of Gujarat State. Health facilities were assigned to two different levels of supervision to determine which level would produce more screening by providers, and a greater number of services per client visit. In Senegal, screening was extended to 32 health centers in three regions. Facilities were randomly assigned to two training approaches, training by a single, central level, training team and cascade training by several teams drawn from different levels (e.g. health region, health district).

Statistically significant $(\mathrm{p}<.001)$ increases in the number of services per visit were observed in the intervention groups in both countries. In India, services per visit at large experimental clinics increased by $23 \%$ and by $9 \%$ in satellite clinics, while services per visit in the control sites decreased by $14 \%$ and $16 \%$ respectively. In Senegal, health posts increased services per visit by $19 \%$ in urban and $28 \%$ in rural areas. Large Indian clinics satisfied almost $91 \%$ of service needs at the same visit, while Senegal posts provided almost $85 \%$ of needed services at the same visit. Because they were not fully implemented, the studies in Honduras and Bolivia suffer from serious confounding factors, especially selection bias. However, in both cases women who were screened received more services than women not screened.

During the heavily supervised pilot phase, providers in both India and Senegal screened virtually $100 \%$ of clients. In the scale-up phase in India, approximately $70 \%$ of clients were screened, but there were no reliable group differences. In Senegal, approximately $12 \%$ of clients were screened but there were no reliable group differences,

Systematic screening may have the potential to produce important increases in the number of services provided in many developing country settings, but at the program, rather than the pilot level, the frequency of screening can vary greatly. The factors influencing implementation at the program level needs to be better understood. 


\section{Introduction}

Integration is the process of bringing together vertical services. The rationale for integration in health programs is that clients will receive more needed services, and/or that program efficiency will improve compared to compartmentalized services. We define integration as the proactive provision by service providers of multiple health services in the same facility, at the same time (K. Foreit et al. 2002). Many program clients, especially women with young children, have multiple needs for preventive care but may be unaware that they need additional services, or that the services they need are available. Typically, providers deliver only the service requested by the client and do not identify other needs. This means that the client often leaves the facility with unmet service delivery needs, and that the provider misses an opportunity to render those services.

Although the importance of proactive provider behavior may seem self-evident, many authors have commented on a wide-spread lack of preventive health care screening. A study of women attending public health clinics in Guatemala found that only $16 \%$ of women in need were offered cervical cancer screening, and that $11 \%$ were unaware that well baby services were available (Vernon and J. Foreit 1999). In a large clinic in Peru, clients were asked to name new services they would like the clinic to offer. Thirty-four percent mentioned services that were already available. A study of health facilities in ten African countries found that only about one-quarter of family planning clients received information about STIs and HIV/AIDS (Miller et al.1998). Lack of screening for contraceptive need among postabortion clients has been noted in Kenya (Solo 1999), and lack of screening for breast cancer in the United States (Wender 1993).

One solution to the lack of integration is to identify the client's needs and desires for services when she first arrives for a visit, and to provide those services either during the same visit, at a scheduled subsequent visit, or through referral to another facility.

We have experimented with a simple technique, Systematic Screening, to identify client needs and provide needed services. The technique uses a checklist or brief structured interview. The contents of the job aid can be varied depending on the type of services to be emphasized, providers' preferences, and service delivery point characteristics. Regardless of format, systematic screening guides the provider in discovering unmet client needs and providing needed services.

Systematic Screening was first tested in Latin America. A before and after study in Mexico used a seven-question algorithm and 2-4 hour training of health center staff. The percentage of clients who received offers for breast examination increased from $8 \%$ to $59 \%$; immunizations of children not initially seen for this purpose increased from $4 \%$ to $33 \%$, and the percentage of clients offered family planning services increased from $2 \%$ to $21 \%$ (Vernon and J. Foreit 1999). A randomized control experiment in a large non-governmental organization (NGO) clinic in Peru found that clients in the experimental group received $13 \%$ more services at first visits and $68 \%$ more services than control clients at subsequent visits. (Leon, et al. 1998). Two additional studies in Honduras (Vernon et al. 2005) and Bolivia (J. Foreit et al.) only partially implemented screening ( $11 \%$ of women were screened in Honduras and $45 \%$ in Bolivia ${ }^{1}$ ). Consequently, services per visit received by screened women were compared with services per visit received by women who 
were not screened. In Honduras, screened women received approximately $23 \%$ more services per visit than non-screened women. In Bolivia, screened women received approximately $8 \%$ more services per visit than non-screened women.

The effectiveness of successfully piloted interventions is often diluted when the interventions are implemented on a larger scale. This may also be true for systematic screening, and the low frequency of screening in Honduras and Bolivia, where supervision and training were weak, may be typical of what happens to an intervention when it is implemented on a programmatic scale. Many best practices, such as the Balanced Counseling Strategy (BCS), have encountered similar problems. In Peru, only about 37 percent of providers trained in the technique actually applied it with clients. A second study in Guatemala dramatically increased the use of BCS to over $70 \%$ of providers, but only through levels of supervision impossible to maintain over time (Foreit 2005). This paper reports the results of four Systematic Screening studies in India and Senegal, consisting of a pilot and scale-up study in each country.

\section{Objectives}

A. The objective of the pilot studies was to replicate a potentially important technique previously tested only in Latin America in a greater range of program settings (i.e. India and Senegal).

B. The objective of the scale-up studies was to test ways to maximize provider use of systematic screening when the pilot interventions studies were implemented in larger areas.

\section{Pilot projects}

Country settings: The Reproductive and Child Health $(\mathrm{RCH})$ programme in India offers child survival, safe motherhood, STI/HIV, and family planning services. No system existed to detect additional client needs, even when the needed services were available in the same facility. The study was conducted in Vadodara, a city of approximately 1.3 million, with a mixed Hindu and Muslim population located in the state of Gujarat.

The Senegalese Ministry of Health $(\mathrm{MOH})$ has a policy requiring the integration of Reproductive Health (RH) services, but this policy had not been implemented at the provider level. Data from the 1998 Senegal Situation Analysis indicated that the majority of family planning (FP) clients received little or no information about other reproductive health services (Ministère de la Sante et de l'Action Social, 2000). The current study was conducted in Dakar, the capital of Senegal, and in the rural district of Kebemer. Study methods and results are reported individually for each country and conclusions are presented in a single discussion section. Table 1 summarizes the designs of the pilot studies (Table 6, see below, summarizes the designs of the scaling-up studies). 
Table 1. Senegal and India: Summary of Study Designs

\begin{tabular}{|c|c|c|}
\hline Factor & Senegal & India \\
\hline $\begin{array}{l}\text { Number, type, and } \\
\text { location of sites }\end{array}$ & 4 urban, 4 rural posts & 8 urban clinics, 111 urban posts \\
\hline Staffing patterns & $\begin{array}{l}\text { All posts: nurses, nurse-midwives, and } \\
\text { auxiliary nurses. }\end{array}$ & $\begin{array}{l}\text { Posts: } 1-2 \text { auxiliary nurses; Clinics: doctors, } \\
\text { auxiliary nurse midwives and support staff }\end{array}$ \\
\hline Instrument format & Brief structured questionnaire & Brief structured questionnaire \\
\hline Training & 2.5 days & 1 day \\
\hline Services & $\begin{array}{l}\text { Prenatal care, STI diagnosis and } \\
\text { treatment, family planning, vaccination } \\
\text { of children under } 5 \text { years of age }\end{array}$ & $\begin{array}{l}\text { Prenatal care, infant and child care, family } \\
\text { planning, reproductive health, vaccination of } \\
\text { children less than } 5 \text { years of age, other services. }\end{array}$ \\
\hline Study Design & Pre-Post test & $\begin{array}{l}\text { Randomly assigned experimental and control } \\
\text { groups with Pre-Post test measurements }\end{array}$ \\
\hline $\begin{array}{l}\text { Data collection } \\
\text { technique }\end{array}$ & Screening forms & Screening forms \\
\hline $\begin{array}{l}\text { Observation } \\
\text { period }\end{array}$ & $\begin{array}{l}12 \text { weeks, } 6 \text { before and } 6 \text { after } \\
\text { introduction of screening (June-August } \\
\text { 2004) }\end{array}$ & $\begin{array}{l}20 \text { weeks, } 10 \text { before and } 10 \text { after introduction of } \\
\text { screening (July - November 2004) }\end{array}$ \\
\hline
\end{tabular}

\section{A. Pilot Study I: Screening in Typical Clinics and Health Posts in an Urban Area in India}

\section{(1) Methods}

Design: The design was a pre-test/post-test experimental and control comparison with random assignment to groups. In an attempt to study the effect of systematic screening in typical facilities, eight of eighteen municipal clinics and their affiliated field-worker run health posts (Anganwadi Centers - AWC) were randomly selected for the study, and then randomly assigned to intervention and control groups. AWCs attached to the control clinics comprised the AWC control group while AWCs attached to the intervention clinics formed the intervention group. There were 56 experimental and 55 control AWCs. Sixteen providers staffed the 4 control clinics, and 14 providers staffed the 4 experimental clinics. The study lasted 20 weeks, 10 before and 10 after the intervention. Participants were limited to women ages 15-49 and children less than 5 years of age. Verbal informed consent was obtained from all women for themselves and their children (Khan et al. 2007).

Intervention: The intervention consisted of provider use of a systematic screening form to detect unmet client service needs. Providers received one day of training in the use of the form and were told to offer the needed services during the visit, through future appointments at the same facility, or referral to other facilities (an abbreviated form is shown in the appendix). 
Dependent Variables: The clinic portion of the study measured three dependent variables: (1) Number of services provided per visit, (2) number of appointments per visit, and (3) referrals per visit. The most important dependent variable was the number of services provided per visit, since it was not possible to track the results of appointments and referrals.

Other analyses included types of unmet needs detected, and visit outcomes. Unmet need for all services except family planning was determined by a client response to a "yes" or "no" question (e.g. "Have all your children under age five been completely vaccinated?"). Unmet need for family planning was defined as the number of married women 15-49 who were not pregnant, did not want to get pregnant, but were not contracepting.

Procedure: Because it is not ethical to screen without providing services, prior to the intervention, in both experimental and control groups, information was collected only on services requested and provided. Women entering the clinic were interviewed to determine if they were eligible for the study, obtain demographic characteristics, and learn the principal reasons for visiting the clinic. The client was then given the form to take to the providers she visited. The providers filled in the services they actually provided. The control group continued to use this data collection system during the post intervention period.

In the experimental group, during the post intervention period, women entering the clinic were interviewed using the screening form to determine their eligibility, characteristics, and reason for visiting. The screening form was then given to the women who took it to a provider. In addition to gathering information about services received, the post-test experimental group screening form also collected information on unmet needs and outcomes (e.g. client rejected or accepted the service; the service was provided, or an appointment or referral was made). When the first provider could not provide all required services, she directed the client to the appropriate staff member. At each stop within the clinic, unmet needs and services received were marked on the form. Upon exiting the clinic, clients returned the forms to the interviewer.

Before the study began, it was determined that a full range of information could not be collected in AWCs, and the dependent measure was limited to services per visit.

Research staff was not present to give screening forms to clients, or to retrieve the forms at the end of the visit. Rather, it was up to the provider to initiate screening. Data were obtained from routine service statistics and no data on unmet needs was collected.

Both clinics and AWCs screened clients for: (1) Vaccination and Child health, (2) Family planning, (3) Reproductive health, (4) Postnatal care; and, (5) Other services. These classifications are used by the Vadodara health service statistics system which combines some services into broader categories. For example, "other services" include the distribution of iron tablets and Vitamin A, and some pediatric curative services.

Analyses: Because services per visit are not normally distributed, we used a non-parametric statistic, the Mann - Whitney $U$ to test for differences between groups. The Vadodara clinics also conducted analyses to determine the extent to which detected service needs were provided 
during the study. Other analyses included description of types of unmet needs, and visit outcomes.

\section{(2) Results}

Equivalence of groups: During the pre-intervention period, control clinics provided 3,354 services compared to 4,380 in experimental clinics. In both sets of clinics, the most commonly provided pre-intervention service was Vaccination and Child Health (46\% in control and $51 \%$ in intervention clinics); followed by family planning (18.8\% and $22.7 \%$, respectively), and "other" services $(21.2 \%$ in the control, and $13.5 \%$ in the experimental group). The demographic characteristics of clients in both groups were similar. Mean age of women in both groups was 24 years pre-intervention and 25 years post. Median number of children was two. The only reliable $(\mathrm{p}<.05)$ difference was that control women had a median of seven years of education, and intervention group women, eight years. In the experimental group, 2,675 currently married women 15-49 years of age participated in the study during the pre-intervention period, and 2,910 participated during the post-intervention period. In the control group, 1,999 women participated in the pre-intervention period, and 2,192 post-intervention.

Implementation of the intervention: In the large municipal clinics where interviewers were present, all eligible women were screened. The proportion of clients screened in the AWC posts could not be determined.

Unmet needs: During the post intervention period 2,814 unmet services needs (0.97 per woman) were detected in the experimental group during the post-intervention period. Family planning (53.5\% of all unmet needs) was the most needed service. The large unmet need may be explained by the fact that half of all women attended the clinics to obtain vaccinations and related services for their children, implying that most women were in the extended postpartum period where unmet need is most prevalent (Ross and Winfrey 2001). Additional unmet needs included "other"- mostly nutritional supplements - (21\% of visits), vaccination, child health $(10 \%)$, reproductive health $(9 \%)$, and postnatal care (4\% of visits). As shown in Table 2, almost all women requested services for unmet needs, and over $96 \%$ received them at the same visit.

Table 2. India: Distribution of Service Needs Identified by Type of Service and Outcome

\begin{tabular}{|c|c|c|c|c|c|c|}
\hline \multirow[b]{2}{*}{ Services } & \multirow[b]{2}{*}{$\begin{array}{c}\text { Needs } \\
\text { Identified }\end{array}$} & \multirow{2}{*}{$\begin{array}{c} \\
\text { Service } \\
\text { Provided }\end{array}$} & \multicolumn{4}{|c|}{ How Provided } \\
\hline & & & $\begin{array}{l}\text { At Same } \\
\text { Visit }\end{array}$ & Appointment & Referral & Total \\
\hline $\begin{array}{l}\text { Family } \\
\text { Planning }\end{array}$ & $\begin{array}{l}53.5 \% \\
(1505)\end{array}$ & $\begin{array}{l}97.1 \% \\
(1461)\end{array}$ & $\begin{array}{l}99.7 \% \\
(1457)\end{array}$ & $\begin{array}{l}0.3 \% \\
(4)\end{array}$ & $0.0 \%$ & $\begin{array}{r}100 \% \\
(1461)\end{array}$ \\
\hline $\begin{array}{l}\text { Postnatal } \\
\text { Care }\end{array}$ & $\begin{array}{l}4.5 \% \\
(128)\end{array}$ & $\begin{array}{c}100.0 \% \\
(128)\end{array}$ & $\begin{array}{c}100.0 \% \\
(128)\end{array}$ & $0.0 \%$ & $0.0 \%$ & $\begin{array}{l}100 \% \\
(128)\end{array}$ \\
\hline Child Care & $\begin{array}{l}10.7 \% \\
(300)\end{array}$ & $\begin{array}{l}95.0 \% \\
(285)\end{array}$ & $\begin{array}{l}86.3 \% \\
(246)\end{array}$ & $\begin{array}{c}4.6 \% \\
(13)\end{array}$ & $\begin{array}{c}9.1 \% \\
(26)\end{array}$ & $\begin{array}{l}100 \% \\
(285)\end{array}$ \\
\hline $\begin{array}{l}\text { Reproductive } \\
\text { Health }\end{array}$ & $\begin{array}{l}9.2 \% \\
(258)\end{array}$ & $\begin{array}{l}93.8 \% \\
(242)\end{array}$ & $\begin{array}{l}76.9 \% \\
(186)\end{array}$ & $\begin{array}{c}4.9 \% \\
(12)\end{array}$ & $\begin{array}{c}18.2 \% \\
(44)\end{array}$ & $\begin{array}{l}100 \% \\
(242)\end{array}$ \\
\hline $\begin{array}{l}\text { Other } \\
\text { Services }\end{array}$ & $\begin{array}{l}22.1 \% \\
(623)\end{array}$ & $\begin{array}{l}97.3 \% \\
(606)\end{array}$ & $\begin{array}{l}99.8 \% \\
(605)\end{array}$ & $\begin{array}{l}0.2 \% \\
(1)\end{array}$ & $0.0 \%$ & $\begin{array}{l}100 \% \\
(606)\end{array}$ \\
\hline Total & $\begin{array}{l}100 \% \\
(2814)\end{array}$ & $\begin{array}{l}96.7 \% \\
(2722)\end{array}$ & $\begin{array}{l}96.3 \% \\
(2622)\end{array}$ & $\begin{array}{l}1.1 \% \\
(30)\end{array}$ & $\begin{array}{l}2.6 \% \\
(70)\end{array}$ & $\begin{array}{l}100 \% \\
(2722)\end{array}$ \\
\hline
\end{tabular}


Services per visit: During the pre-intervention period, women in both experimental and control clinics requested a mean of 1.01 services per visit. However, a mean of 1.79 services per client visit was actually provided in the control group compared to 1.62 in the experimental group, indicating that services per visit were slightly lower in the experimental clinics at pre-test. In both groups more services were received than initially requested, suggesting that clinic staff were proactively identifying clients' needs before the experiment began. Post-intervention, experimental clinics increased services by approximately $22 \%$, while in control clinics services declined by approximately $14 \%$. As shown in Table 3, all differences are statistically reliable $(\mathrm{p}<.001)$.

Table 3. India: Services Per Visit: Experimental and Control Groups

\begin{tabular}{|c|c|c|c|c|c|c|c|}
\hline \multirow[b]{2}{*}{ Clinic } & \multicolumn{3}{|c|}{ Pre-intervention period } & \multicolumn{3}{|c|}{ Post-intervention period } & \multirow[b]{2}{*}{$\begin{array}{l}\text { Percent } \\
\text { change }\end{array}$} \\
\hline & $\begin{array}{c}\text { Visits } \\
(\mathrm{N})\end{array}$ & $\begin{array}{l}\text { Services } \\
\text { (N) }\end{array}$ & $\begin{array}{c}\text { Mean } \\
\text { services } \\
\text { per visit }\end{array}$ & $\begin{array}{l}\text { Visits } \\
(\mathrm{N})\end{array}$ & $\begin{array}{c}\text { Services } \\
\text { (N) }\end{array}$ & $\begin{array}{c}\text { Mean } \\
\text { services } \\
\text { per visit }{ }^{\star}\end{array}$ & \\
\hline \multicolumn{8}{|c|}{ Control Group } \\
\hline Navi Dharti & 329 & 425 & 1.29 & 294 & 337 & 1.15 & -11.6 \\
\hline Fatehpura & 482 & 737 & 1.53 & 717 & 840 & 1.17 & -23.5 \\
\hline Gotri & 704 & 1660 & 2.36 & 628 & 1402 & 2.23 & -5.5 \\
\hline Sawad & 484 & 750 & 1.55 & 553 & 775 & 1.40 & -9.7 \\
\hline Total & 1999 & 3572 & 1.79 & 2192 & 3354 & 1.53 & -14.5 \\
\hline \multicolumn{8}{|c|}{ Experimental Group } \\
\hline Gorva & 495 & 721 & 1.46 & 649 & 1206 & 1.86 & 27.4 \\
\hline Bauchawad & 435 & 614 & 1.41 & 444 & 680 & 1.53 & 8.5 \\
\hline Navayard & 713 & 1318 & 1.85 & 875 & 1986 & 2.27 & 22.7 \\
\hline $\begin{array}{l}\text { Old Padra } \\
\text { Road }\end{array}$ & 1032 & 1727 & 1.67 & 942 & 1935 & 2.05 & 22.8 \\
\hline Total & 2705 & 4380 & 1.64 & 2910 & 5807 & 2.00 & 21.7 \\
\hline
\end{tabular}

Statistical significance of the overall results is largely an artifact of sample size. A more meaningful evaluation of the intervention is a simple comparison of percent changes in services per visit in each of the study clinics. In the post intervention period, the ratio of services per visit in each of the four control group clinics declined by $5-23 \%$ depending on the clinic, but increased in each of the four intervention clinics by $8-28 \%$, depending on the clinic. The $10-$ day Hindu festival of Navratri took place during the intervention period ${ }^{2}$. Anecdotal reports indicate that many providers in both the experimental and control clinics took at least one day's vacation during the festival. Systematic screening may have at least partially overcome the effect of the festival on services provided to the experimental group. 
The increase in total services per visit was driven by the provision of more family planning services to women who visited the clinic for vaccination of children. In the pre-intervention period, control group women bringing children for vaccination received an average of 0.37 family planning services per vaccination. In the post-intervention period, the ratio in the control group was almost unchanged, $0.36: 1$. In comparison, the ratio of family planning services to vaccination visits in the experimental group increased from 0.42:1 to $0.62: 1$.

Anganwadi Centers: In the AWCs, there were 911 clients in the experimental group preintervention and 605 post-intervention. In the control group, there were 877 clients pre- and 753 post-intervention. Client profiles were similar in both groups. Control clients were a median of 24 years of age pre-intervention and 25 post-intervention. Experimental group clients were a median of 24 years of age throughout the study. In both groups, the median number of living children was two. Years of education was the only statistically significant $(p<.05)$ difference between groups. Women visiting the experimental Centers had a median of 7 years of education compared to 5 for controls.

Control AWCs provided a mean of 1.62 services per visit during the pre-intervention period, and 1.36 post-intervention, a decline of approximately $16 \%$. Experimental AWCs provided a mean of 1.48 services per visit during the pre-test and 1.61 services during the post-test period, an increase of nine percent. All differences are statistically reliable ( $<<.05)$. In intervention centers, an increase in family planning services was responsible for most of the increase in services per visit (data not shown).

\section{B. Pilot Study II: Screening in High Performing Urban and Rural Health Posts in Senegal}

\section{(1) Methods}

Design: A simple before and after design was used in four urban health posts in Dakar and three in the rural area of Kebemer. Health authorities regarded the posts as above average in administration and performance. The rational for selecting these posts was the belief that they would be better able to follow the research protocols. Participants were women 15-49 and children under five years of age. Verbal informed consent was obtained from all women for themselves and their children (Sanogo et al. 2005).

Intervention: The intervention consisted of applying an instrument similar to that in India for screening clients. The major difference between the Indian and Senegalese interventions is that providers received two and a half days of training rather than one day.

Dependent variables: As in India, dependent variables included (1) Number of services provided per visit, (2) number of appointments per visit, and (3) referrals per visit. Other analyses included types of unmet needs detected, and visit outcomes. Unmet demand for family planning as well as unmet need was calculated for Senegal.

Procedure: During the post-intervention period, providers screened for (1) prenatal visits, (2) prenatal tetanus vaccine, (3) family planning, (4) child vaccination; and, (5) child growth and development. 
Pre-intervention data collection was limited to exit interviews to obtain information on services requested and received. Information was obtained at exit interviews using the same questionnaire used at pre-intervention. Information on unmet need for services was obtained from the screening forms used by providers which interviewers collected at the end of each day.

Analysis: The Mann-Whitney U was used to analyze group differences. Analyses were also conducted to determine the extent to which detected service needs were satisfied during the study. Other analyses included types of unmet needs detected, and visit outcomes.

\section{(2) Results}

Implementation of the Intervention: In Dakar, interviews were conducted at 3759 eligible client visits, and 3831 visits were screened. In Kebemer, interviews were conducted at 1461 visits, and 1472 were screened. Interviews are the source of data on the number of visits.

Equivalence of groups: Based on interviews, 5,652 visits were made to posts in Dakar and Kebemer prior to the intervention and 5,220 after. Before and after the intervention, the median age group was 25-27 years, and median education was incomplete primary schooling. The reasons for visiting health posts were similar in the pre- and - post intervention periods. During both periods the most common services provided were prenatal care $(41.8 \%$ pre- and $41.3 \%$ post), vaccination of children (32.4\% pre- and 30.1\% post), and family planning (14.8\% pre- and $17.9 \%$ post). Family planning visits were almost four times as frequent in urban posts as in rural during both study periods ( $18.6 \%$ vs. $4.9 \%$ pre-intervention and $22.8 \%$ vs. $5.6 \%$ post).

Unmet needs: In Dakar, clients averaged 0.58 unmet service needs per visit, and in Kebemer, 1.02 per visit. The unmet needs most frequently detected during screening included childhood growth and development visits, prenatal tetanus injection, and diagnosis and treatment of reproductive tract infections (unmet needs for services related to reproductive tract infection services was determined by using the Syndromic Approach: Providers asked women if they had any recent vaginal pain or discharge). As the most common reason for visiting the health posts was to receive prenatal care, few Kebemer clients had an unmet need for this service ( 80 of 2213 , or $3.6 \%$ of pregnant women were not receiving prenatal care). However, health authorities believed that services believed that tetanus vaccination was not being sufficiently included in pre-natal care.

This study calculated unmet demand, rather than only unmet need for family planning. Unmet need is essentially the number of non-pregnant women who are not trying to get pregnant but are not using family planning. Unmet demand is the number of women with an unmet need who actually want to use a contraceptive. In Dakar and Kebemer, 1271 married women 15-49 years of age had an unmet need for family planning, but only $186(14.6 \%)$ had unmet demand. The most frequent reasons for not using family planning were breastfeeding, postpartum amenorrhea, and abstinence. Table 4 shows unmet service needs, and services provided by district. 
Table 4. Senegal: Distribution of Service Needs Identified by Type of Service and Outcome

\begin{tabular}{|c|c|c|c|c|c|c|}
\hline \multirow[b]{2}{*}{ Services } & \multirow[b]{2}{*}{$\begin{array}{c}\text { Needs } \\
\text { Identified }\end{array}$} & \multicolumn{5}{|c|}{ How Provided } \\
\hline & & $\begin{array}{l}\text { Service } \\
\text { Provided }\end{array}$ & $\begin{array}{c}\text { At Same } \\
\text { Visit }\end{array}$ & Appointment & Referral & Total \\
\hline \multicolumn{7}{|l|}{ DAKAR } \\
\hline Prenatal Visit & $\begin{array}{c}2.8 \% \\
(60)\end{array}$ & $\begin{array}{c}11.7 \% \\
(7)\end{array}$ & $\begin{array}{c}100 \% \\
(7)\end{array}$ & $0.0 \%$ & $0.0 \%$ & $\begin{array}{c}100 \% \\
(7)\end{array}$ \\
\hline $\begin{array}{l}\text { Prenatal } \\
\text { Tetanus }\end{array}$ & $\begin{array}{l}27.7 \% \\
(600)\end{array}$ & $\begin{array}{c}74.5 \% \\
(447)\end{array}$ & $\begin{array}{c}90.2 \% \\
(403)\end{array}$ & $\begin{array}{l}9.8 \% \\
(44)\end{array}$ & $0.0 \%$ & $\begin{array}{l}100 \% \\
(447)\end{array}$ \\
\hline $\begin{array}{c}\text { Family } \\
\text { Planning }\end{array}$ & $\begin{array}{l}5.8 \% \\
(125)\end{array}$ & $\begin{array}{c}76.8 \% \\
(96)\end{array}$ & $\begin{array}{l}25 \% \\
(24)\end{array}$ & $\begin{array}{l}72.9 \% \\
(70)\end{array}$ & $\begin{array}{c}2.1 \% \\
(2)\end{array}$ & $\begin{array}{c}100 \% \\
(96)\end{array}$ \\
\hline $\begin{array}{c}\text { Reproductive } \\
\text { Tract } \\
\text { Infection }\end{array}$ & $\begin{array}{c}24.3 \% \\
(528)\end{array}$ & $\begin{array}{c}92.4 \% \\
(488)\end{array}$ & $\begin{array}{c}98.0 \% \\
(478)\end{array}$ & $\begin{array}{c}2.0 \% \\
(10)\end{array}$ & $0.0 \%$ & $\begin{array}{l}100 \% \\
(488)\end{array}$ \\
\hline $\begin{array}{c}\text { Child } \\
\text { Vaccination }\end{array}$ & $\begin{array}{l}3.9 \% \\
(85)\end{array}$ & $\begin{array}{c}38.8 \% \\
(33)\end{array}$ & $\begin{array}{c}24.2 \% \\
(8)\end{array}$ & $\begin{array}{l}75.8 \% \\
(25)\end{array}$ & $0.0 \%$ & $\begin{array}{c}100 \% \\
(33)\end{array}$ \\
\hline $\begin{array}{l}\text { Child Growth } \\
\text { and } \\
\text { Development }\end{array}$ & $\begin{array}{c}35.5 \% \\
(771)\end{array}$ & $\begin{array}{c}79.4 \% \\
(612)\end{array}$ & $\begin{array}{c}(98.7 \%) \\
(604)\end{array}$ & $\begin{array}{c}(1.3 \%) \\
(8)\end{array}$ & $0.0 \%$ & $\begin{array}{l}100 \% \\
(612)\end{array}$ \\
\hline Total Dakar & $\begin{array}{l}100 \% \\
(2169)\end{array}$ & $\begin{array}{l}77.5 \% \\
(1683)\end{array}$ & $\begin{array}{l}90.6 \% \\
(1524)\end{array}$ & $\begin{array}{l}9.3 \% \\
(157)\end{array}$ & $\begin{array}{c}0.1 \% \\
(2)\end{array}$ & $\begin{array}{l}100 \% \\
(1683)\end{array}$ \\
\hline \multicolumn{7}{|l|}{ KEBEMER } \\
\hline Prenatal Visit & $\begin{array}{l}1.3 \% \\
(20)\end{array}$ & $\begin{array}{l}45.0 \% \\
(9)\end{array}$ & $\begin{array}{l}22.2 \% \\
(2)\end{array}$ & $\begin{array}{l}77.8 \% \\
(7)\end{array}$ & $0.0 \%$ & $\begin{array}{c}100 \% \\
(9)\end{array}$ \\
\hline $\begin{array}{l}\text { Prenatal } \\
\text { Tetanus }\end{array}$ & $\begin{array}{l}34.9 \% \\
(521)\end{array}$ & $\begin{array}{l}71.0 \% \\
(370)\end{array}$ & $\begin{array}{l}70.8 \% \\
(262)\end{array}$ & $\begin{array}{l}29.2 \% \\
(108)\end{array}$ & $0.0 \%$ & $\begin{array}{l}100 \% \\
(370)\end{array}$ \\
\hline $\begin{array}{c}\text { Family } \\
\text { Planning }\end{array}$ & $\begin{array}{l}3.8 \% \\
(56)\end{array}$ & $\begin{array}{c}75.0 \% \\
(42)\end{array}$ & $\begin{array}{c}4.8 \% \\
(2)\end{array}$ & $\begin{array}{c}95.2 \% \\
(40)\end{array}$ & $0.0 \%$ & $\begin{array}{c}100 \% \\
(42)\end{array}$ \\
\hline $\begin{array}{l}\text { Reproductive } \\
\text { Tract } \\
\text { Infection }\end{array}$ & $\begin{array}{c}27.1 \% \\
(405)\end{array}$ & $\begin{array}{c}95.6 \% \\
(404)\end{array}$ & $\begin{array}{c}95.8 \% \\
(387)\end{array}$ & $\begin{array}{c}4.0 \% \\
(16)\end{array}$ & $\begin{array}{c}0.2 \% \\
(1)\end{array}$ & $\begin{array}{l}100 \% \\
(404)\end{array}$ \\
\hline $\begin{array}{c}\text { Child } \\
\text { Vaccination }\end{array}$ & $\begin{array}{l}2.6 \% \\
(39)\end{array}$ & $\begin{array}{l}51.3 \% \\
(20)\end{array}$ & $\begin{array}{c}50.0 \% \\
(10)\end{array}$ & $\begin{array}{c}35.0 \% \\
(7)\end{array}$ & $\begin{array}{c}15 \% \\
(3)\end{array}$ & $\begin{array}{c}100 \% \\
(20)\end{array}$ \\
\hline $\begin{array}{l}\text { Child Growth } \\
\text { and } \\
\text { Development }\end{array}$ & $\begin{array}{c}30.3 \% \\
(452)\end{array}$ & $\begin{array}{c}77.2 \% \\
(349)\end{array}$ & $\begin{array}{c}70.5 \% \\
(246)\end{array}$ & $\begin{array}{c}29.5 \% \\
(103)\end{array}$ & $0.0 \%$ & $\begin{array}{l}100 \% \\
(349)\end{array}$ \\
\hline $\begin{array}{c}\text { Total } \\
\text { Kebemer }\end{array}$ & $\begin{array}{l}100 \% \\
(1493)\end{array}$ & $\begin{array}{c}80 \% \\
(1194)\end{array}$ & $\begin{array}{c}76.1 \% \\
(909)\end{array}$ & $\begin{array}{c}23.5 \% \\
(281)\end{array}$ & $\begin{array}{c}0.3 \% \\
(4)\end{array}$ & $\begin{array}{c}99 \% \\
(1194)\end{array}$ \\
\hline $\begin{array}{l}\text { GRAND } \\
\text { TOTAL } \\
\text { (Dakar and } \\
\text { Kebemer) }\end{array}$ & $\begin{array}{l}100 \% \\
(3662)\end{array}$ & $\begin{array}{l}78.6 \% \\
(2877)\end{array}$ & $\begin{array}{l}84.6 \% \\
(2433)\end{array}$ & $\begin{array}{c}15.2 \% \\
(438)\end{array}$ & $\begin{array}{c}0.2 \% \\
(6)\end{array}$ & $\begin{array}{r}100 \% \\
(2877)\end{array}$ \\
\hline
\end{tabular}


About $72 \%$ of needed services in Dakar and $79 \%$ in Kebemer were provided at the same visit or referrals. Table 4 shows unmet service needs identified, services requested. Compared to India, Senegal provided fewer services at the same visit, and made many more appointments. Less than $5 \%$ of family planning services in Kebemer and $25 \%$ in Dakar were provided at the same visit. In contrast, appointments were made in $95 \%$ of cases in Kebemer and $73 \%$ of cases in Dakar. A possible explanation of the high number of appointments is that the Senegalese Ministry of Health requires that women be menstruating to receive family planning. Additionally, this service is somewhat more expensive than other services offered in health posts.

Table 5. Senegal: Services per visit pre- and post intervention by Area

\begin{tabular}{|c|c|c|c|c|c|c|c|}
\hline \multicolumn{4}{|c|}{ Pre-Intervention } & \multicolumn{4}{|c|}{ Post-Intervention } \\
\hline \multicolumn{8}{|c|}{ Dakar Posts } \\
\hline Post & $\begin{array}{l}\text { Visits } \\
\text { (N) }\end{array}$ & $\begin{array}{l}\text { Services } \\
\text { (N) }\end{array}$ & $\begin{array}{c}\text { Mean Services } \\
\text { per Visit }\end{array}$ & $\begin{array}{l}\text { Visits } \\
\text { (N) }\end{array}$ & $\begin{array}{l}\text { Services } \\
\text { (N) }\end{array}$ & $\begin{array}{l}\text { Mean Services } \\
\text { Per Visit }{ }^{*}\end{array}$ & $\begin{array}{l}\text { Percent } \\
\text { Change }\end{array}$ \\
\hline Derkle & 722 & 801 & 1.12 & 1062 & 1360 & $1.28^{*}$ & 14.3 \\
\hline $\begin{array}{l}\text { Georges } \\
\text { Lahoud }\end{array}$ & 1171 & 1358 & 1.16 & 799 & 1166 & $1.46^{*}$ & 25.9 \\
\hline HLM 1 & 1805 & 2184 & 1.21 & 1281 & 1909 & $1.49^{*}$ & 23.1 \\
\hline Liberte 4 & 371 & 449 & 1.21 & 617 & 814 & $1.32^{*}$ & 9.1 \\
\hline Total Dakar & 4069 & 4792 & 1.18 & 3759 & 5249 & $1.40^{*}$ & 18.6 \\
\hline \multicolumn{8}{|c|}{ Kebemer Posts } \\
\hline Diokoul & 340 & 462 & 1.36 & 436 & 854 & $1.96^{*}$ & 44.0 \\
\hline Gueoul & 641 & 1031 & 1.61 & 597 & 1081 & $1.81^{*}$ & 12.4 \\
\hline Sagatta & 568 & 727 & 1.28 & 428 & 676 & $1.58^{*}$ & 23.4 \\
\hline $\begin{array}{c}\text { Total } \\
\text { Kebemer }\end{array}$ & 1583 & 2220 & 1.40 & 1461 & 2611 & $1.79^{*}$ & 27.8 \\
\hline
\end{tabular}

${ }^{*}$ All pre-post and experimental and control differences are statistically significant at $\mathrm{p}<.001$

The most common service provided in Dakar and Senegal was pre-natal tetanus vaccination. Post-intervention 817 services were provided in both locations compared to 862 prior to the intervention, suggesting that screening did not improve coverage, perhaps because it was already at high levels.

Services and appointments per visit: For all posts, the mean number of services per visit provided before the intervention was 1.23 and 1.51 after the intervention, a significant $(\mathrm{p}<.001)$ increase of almost 23\%. In Dakar, services per visit increased by approximately $19 \%$ and in Kebemer by $28 \%$. In both Dakar and Kebemer the modal number of services per visit increased from one to two. Statistical significance in this study, as in India, is largely the product of large sample sizes. More importantly, all health posts increased services per visit, and all but one increased by over $10 \%$. The increase in services per visit was largely the result of screening for many more reproductive tract infections (RTI). Prior to the intervention, only 187 RTI services were provided in both districts. Post-intervention, the number was 1123.

Table 5 shows the mean number of services and appointments received before and after the intervention for all posts included in the study. Although the number of services increased, the intervention did not have an important impact on referrals which increased by $2 \%$. 


\section{Scale up studies}

As in the pilot phase, two brief studies were conducted. Contrary to the pilot phase, the study in Senegal was a true experiment, while the study in India was a quasi-experiment. In both studies, measurement was made as unobtrusive as possible to replicate normal program conditions as opposed to research and pilot conditions. FRONTIERS provided no funds for scale up, and all staff, including data collection staff were regular ministry employees. FRONTIERS covered research costs only.

Table 6. Senegal and India: Summary of Scaling-up Study Designs

\begin{tabular}{|l|l|l|}
\hline \multicolumn{1}{|c|}{ Factor } & \multicolumn{1}{|c|}{ Senegal } & \multicolumn{1}{c|}{ India } \\
\hline $\begin{array}{l}\text { Number, type, and } \\
\text { location of sites }\end{array}$ & $\begin{array}{l}16 \text { urban health centers and } 36 \text { urban } \\
\text { and rural posts }\end{array}$ & 63 urban and rural health centers and posts \\
\hline Staffing patterns & $\begin{array}{l}\text { Urban health centers: Physicians, } \\
\text { nurses, nurse-midwives, and auxiliary } \\
\text { nurses. } \\
\text { All posts: nurses, nurse-midwives, and } \\
\text { auxiliary nurses. }\end{array}$ & $\begin{array}{l}\text { Posts: 1-2 auxiliary nurses; Clinics: doctors, } \\
\text { auxiliary nurse midwives and support staff }\end{array}$ \\
\hline Instrument format & Brief structured questionnaire & Brief structured questionnaire \\
\hline Training & 2.5 days & 1 day \\
\hline Services & $\begin{array}{l}\text { Prenatal care, STI diagnosis and } \\
\text { treatment, family planning, vaccination } \\
\text { of children under 5 years of age }\end{array}$ & $\begin{array}{l}\text { Prenatal care, infant and child care, family } \\
\text { planning, reproductive health, vaccination of } \\
\text { children less than 5 years of age, other services. }\end{array}$ \\
\hline Study Design & $\begin{array}{l}\text { True experiment : Intervention and } \\
\text { control groups }\end{array}$ & $\begin{array}{l}\text { Quasi-experiment, intervention and comparison } \\
\text { group, }\end{array}$ \\
\hline $\begin{array}{l}\text { Data collection } \\
\text { technique }\end{array}$ & Service statistics & $\begin{array}{l}\text { Service statistics, Mystery Clients, Exit } \\
\text { interviews }\end{array}$ \\
\hline $\begin{array}{l}\text { Observation } \\
\text { period }\end{array}$ & 16 weeks & \begin{tabular}{l}
12 weeks \\
\hline
\end{tabular}
\end{tabular}

\section{A. Scale up Study I: Testing the Effect of Alternative Supervisory and Feedback Systems on the Frequency of Screening by Providers in India}

The scale-up study in India manipulated three factors, commitment by high level program decision makers, provider training, and supervision to determine if higher levels of each would result in more provider screening of clients than more routine levels. 


\section{(1) Methods}

Following the success of the pilot study in Vadodara, the state of Gujarat decided to initially scale up systematic screening to 63 health centers and posts in three districts. Two new supervisory and feedback systems were tested, using non-random assignment; 28 urban and 12 rural clinics (total 40 service delivery points)were assigned to the intervention group, and 11 urban and 12 rural clinics (total 23 service delivery points) were assigned to the comparison group. Comparison group urban clinics were located in the city of Vadodara while intervention group urban clinics were located in the city of Surat. The locations of rural clinics were the reverse of the location of urban clinics. Intervention rural clinics came from an area near Surat, while control rural clinics came from an area near Vadodara. Duration of fieldwork was three months.

Independent variables: The study in urban clinics included four independent variables: (1) expressed commitment to the intervention by senior program administrators, (2) types of training, (3) types of supervision, and (4) type of screening form used. In rural areas one variable, supervision was manipulated.

Commitment: In the intervention group, letters to providers explaining the new intervention and its importance were signed by higher ranking officials than in the comparison group, and introductory talks at the beginning of training in screening were given by higher ranking officials in intervention rather than comparison groups.

Training: In intervention urban clinics, doctors, vaccinators and counselors and auxiliary nurse midwives were trained. In comparison urban clinics, only doctors and auxiliary nurse midwives were trained.

Supervision: Intervention group clinics received more frequent supervision than comparisons (2 visits vs. 1 during the observation period).

Instrument: Two different screening instruments were used in the study. Urban clinics in the comparison group used a modified service statistics form that included the screening form. The intervention group used a separate screening instrument.

Dependent variables in all clinics included number of clients screened, additional service needs discussed by providers with clients, and mean number of services per visit. Data was gathered from exit interviews and mystery client interviews in urban clinics and from exit interviews in rural clinics.

\section{(2) Results}

The study design contained serious problems. The intervention and comparison clinics were not comparable. Urban intervention group clinics had more clients and providers (especially physicians) different patient flow procedures, and were better managed than comparison clinics. Physicians in urban intervention clinics were allowed to choose the patients they would or would not screen. In rural areas, control posts provided a broader array of services than intervention clinics The frequency of supervisory visits to comparison clinics was not reported. The confounds 
and lack of important information make it impossible to attribute study results to the interventions.

There was no statistically reliable difference between rural groups. Both intervention and comparisons screened about $70 \%$ of clients using the separate systematic screening forms. In urban clinics, $100 \%$ of comparison group clients (using the service statistics version of the form) were screened compared to $73 \%$ of intervention clients $(\mathrm{p}<.001)$.

Exit interviews reported that urban intervention group providers discussed significantly more $(\mathrm{p}<$ $.01 ; \mathrm{n}=1063)$ needs than did urban comparison group providers (2.5 vs. 2.2). Rural intervention providers also asked about significantly more $(\mathrm{p}<.001)$ needs than rural comparison group providers. In urban clinics the data from 99 mystery client data also indicate that somewhat more needs were discussed by intervention than comparison group providers (2.9 vs. 2.4).

Although intervention group providers apparently asked more questions than comparison group providers, the amount of screening does not appear to be related to the number of services received per visit. Clients in urban comparison group clinics received a mean of 1.9 services per visit versus a mean of 1.8 services per visit in the intervention group. In rural clinics, comparison and intervention group women both received a mean of 1.5 services per visit.

\section{B. Scale up Study II: Testing the Effect of Training on Provider Use Of Systematic Screening in Senegal}

The scale-up study in Senegal manipulated a single factor, training to determine if training of providers by a single group of central level trainers would result in greater provider screening of clients than the traditional, "cascade" training system where central level trainers train regional trainers who train district trainers, etc.

\section{(1) Methods}

After the success of the pilot study, the Senegal Ministry of Health began to scale up systematic screening in early 2007. The first phase included 50 facilities including 14 health centers and 36 health posts located in both urban and rural areas (centers are generally large facilities that offer a greater range of services than posts) in Dakar, Louga and Fatick health regions. Facilities were randomly assigned to intervention (training by central level trainers) and control (cascade training) groups. The intervention group included 6 health centers and 19 health posts. The control, 8 centers and 17 posts. The observation period lasted for four months after training.

Independent variable: Training by central level trainers (intervention group) consisted of 1.5 days of training in screening. Training was held in a single district health center and attended by all health post and health center staff in the region. In cascade training (control group) central level trainers train district level trainers who, in turn, train facility staff. Training of trainers in the cascade system consisted of 1.5 days of training in screening, as well as an additional day on how to train. 
The dependent variable was the percent of eligible clients (women ages 15-44) screened. To estimate the proportion of eligible women screened, service providers were asked to mark in $\mathrm{X}$ in the comments section of register that they kept daily that included the names and services received by each client.

\section{(2) Results}

A total of 85 providers were trained in the intervention group (central training) and 37 (44\%) actually screened clients. In the control group (cascade training) 73 providers were trained and 42 $(58 \%)$ actually screened clients. About half of the providers trained either did not keep records (matrons, social assistants and community agents) or were doctors who played mainly supervisory rather than service delivery roles in RH services. Also, many providers reported that it was not always possible to report screening. Many facilities experienced stock outs of client registry forms during the study period, and some kept no records on reproductive health services at all.

The group receiving central level training screened more $(\mathrm{p}<.001)$ clients, 3,364 out of 15,976 $(21 \%)$ than the group receiving cascade training, 2826 out of 20,329 (14\%). Although central level training appears more effective than cascade training, only $17 \%$ of the 36,305 eligible reproductive health clients were actually screened.

Facility size appears to influence screening which was higher in health posts where $22 \%$ of clients were screened than in health centers where $13 \%$ of clients were screened. Screening by providers was much lower in the large health facilities in the city of Dakar (8\% screening) than in the smaller facilities outside Dakar (22\%). Finally, time since training may also influence provider behavior. Screening increased steadily from $15 \%$ during the first two months of the study to $18 \%$ in the third, and $19 \%$ in the fourth.

\section{Discussion}

\section{A. Pilot Studies}

Systematic screening appears to be an effective and robust technique for increasing the number of services per visit in different settings. In both India and Senegal, screening was successful in increasing the number of services per visit in every facility studied. In India screening was also successful in increasing the number of services delivered by auxiliary nurses. Providers in India were proactive in providing services before the intervention, but the addition of a formal screening technique resulted in an even larger number of services, suggesting that making screening systematic can improve results even when providers are already proactive.

The results also indicate that the type of additional services provided because of screening are dependent on two factors: (1) the characteristics of the clients attending the clinics, and (2) service delivery procedures. In India, where approximately half of all clients were in the postpartum period, the most common type of additional service was family planning. In Senegal where the most common service was prenatal care, fewer women had an unmet demand for family planning, and the service was difficult to receive because of medical requirements. Rather, the program choose to focus on ante-natal tetanus and reproductive tract infections, with the latter accounting 
for the greatest increase in services per visit. Given the large number of tetanus shots prior to the intervention, the usefulness of focusing on this intervention may be questionable, as is the focus on RTI determined by the Syndromic approach.

A limitation to the India study was the lack of control over the AWC portion of the study, and the consequent inability to control for confounding factors including selection bias, and a lack of comparability with the instruments and procedures used in the large Vadodara clinics and in Senegal. However, the results from the AWC clinics did parallel those of Vadodara clinics and Senegal posts.

Senegal used a simple before and after design without a control group because of concerns about the feasibility of using more elaborate designs. The before and after design fails to control for factors such as secular trends, seasonality, or random fluctuations in the number of visits or services. However, the indicator services per visit is less subject to random fluctuation than either visits or services alone. Also, the study was brief, reducing the possibility of a history confound. Finally, previous research, including true experiments, indicating the effectiveness of systematic screening support the use of a simple design in Senegal

Our findings are consistent with those in Vadodara and with those earlier studies in Peru (Leon et al. 1999) and Guatemala (Vernon and J. Foreit 1999), as well as in the partially implemented Bolivia (J. Foreit et al. 2005), and Honduras (R.Vernon et al.2006) studies.

In these studies integration at the provider level increased the number of services received by clients. We infer that integration also improved productivity because the same staff provided more services per visit than prior to the introduction of screening.

Increasing services per visit by roughly 10 - 20 percent improves provider productivity, but also increases program costs. If implemented on a large scale, an effective screening program would result in large variable cost increases and possible increases in fixed costs. Prior to implementing systematic screening, programs need to estimate potential cost increases and plan the pace and extent of scale-up accordingly.

In both the India and Senegal virtually all clients were screened, but the intervention periods were brief and researchers distributed and collected screening forms. It is questionable whether such high levels of screening could be attained in a routine program setting. Program monitoring and supervision will need to focus on provider compliance in using the screening technique, and future research will need to focus on methods for ensuring compliance. Opportunities for provider compliance studies are fairly numerous with systematic screening being scaled-up in India and Senegal, and replicated at pilot levels in Bangladesh, Madagascar, Rwanda, and the Philippines.

\section{B. Scale-up studies}

These studies were conducted to determine what factors might determine the success of scalingup systematic screening. The India scale-up study varied several factors, but problems with the research design resulted in contradictory findings. However, the integration of systematic screening into the routine service statistics form may be an important innovation because it 
resulted in $100 \%$ client screening, but the innovation should be tested again before it is recommended as a best practice

The Senegal study did find that the type of training did influence performance in a normal program situation. Cascade training, a trainer of trainers approach resulted in less screening than did training all providers by a single team of trainers from the Ministry of Health central level. Differences in the skill levels of professional trainers at the central level and amateur trainers at lower levels may account for the difference. In Senegal it was also found that the number of providers actually in a position to screen clients, or to report screening, accounted for only about half the number of providers trained. Thus, inefficient and ineffective training does influence screening, while stock outs of service statistics forms contributes to under-reporting of screening.

Facility size was also a factor that appears to influence screening. Larger facilities screen fewer clients than smaller facilities, perhaps because providers in large facilities saw more clients and had less time to screen. Finally, a slight trend toward greater screening over time was observed. If increased screening over time is a frequent occurrence, future scale-up studies should use longer, rather than shorter periods of observation.

Pilot studies have demonstrated the effectiveness of systematic screening under controlled pilot conditions. But the Senegal study confirmed our hypothesis that much lower levels of screening would be encountered in a normal program expansion. This appears to be influenced by the quality of training, facility size, and perhaps reporting forms. As far as can be determined, given the design problems, a large proportion of clients in India were screened. This suggests that the overall strength of the service delivery system (assuming the Gujarat system is stronger than the Senegal system), rather than a few individual factors determines the relative success of scaling up an intervention tested on a small scale in a pilot or controlled experiment.

Solutions to the problem of maintaining the effectiveness of a pilot intervention when it is expanded to program scale will require more research. To date there has been almost no research on this topic. Solving problems related to bringing successful interventions to scale should become a priority for operations research, and this may mean reducing the number of pilots and small experiments in favor of broader interventions. 


\section{Notes}

(1) Both the Honduras and Bolivia studies used a before and after design. Failure to implement in Honduras appears to be due to a very short period of training for screeners ( 2 hours), and a failure to supervise. In Bolivia, impassable roads made supervision impossible for most of the post-test period.

(2) Navrati is a Hindu Festival that lasts for nine nights and ten days that honors the goddess Durga. The festival is held in the period of September-October. Navratri is an especially important celebration in the study location, the city of Vadodara.

(www. Ahmedabadcity.com/tourism/html/navratri.html accessed 4/18/2008). 


\section{References}

Fatou Nar Mbaye, et al. May 2008. Studying Provider Compliance with Systematic Screening during Scale-up in Senegal, June 2008

Foreit, James R. et al. 2005. Use of systematic screening to increase the provision of reproductive health services in Bolivia, FRONTIERS Final Report. Washington DC: Population Council.

Foreit, J. et al. 2005. Use of systematic screening to increase the provision of reproductive health services in Bolivia, FRONTIERS Final Report. Washington DC: Population Council.

Foreit, Karen G. Fleischman et al. 2002. When does it make sense to consider integrating STI and HIV services with family planning services? International Family Planning Perspectives 28(2): 105-107.

Khan, M.E. et al. 2007. Using Systematic Screening to Integrate Reproductive Health Services in Vadodara, India. Journal of Family Welfare Vol. 53(2): 73-79.

Khan, M.E. et al. March 2008 Studying Provider Compliance with Systematic Screening During Scale-up in Gujarat, unpublished FRONTIERS final report

Leon, F. et al. 1998. Increasing Use of Reproductive Health Services in a Peruvian Clinic. In Foreit J, Frejka, T (eds). Family Planning Operations Research: A Book of Readings. New York: Population Council, 239-245.

Miller, Kate et al. 1998. Clinic-Based Family Planning and Reproductive Health Services in Africa: Findings from Situation Analysis Studies. New York: Population Council, 197.

Ross, John A., Winfrey, William L. 2001. Contraceptive Use, Intention to Use and Unmet Need during the Extended Postpartum Period. International Family Planning Perspectives 27(1): 2027.

Sanogo, D. et al. 2005. Using systematic screening to increase integration of reproductive health services delivery in Senegal, FRONTIERS Final Report. Washington, DC: Population Council.

Senegal, Ministere de la Sante et de l'Action Social, Population Council. 2000. Evolution des services de sante de la reproduction et de planification familiale de 1994 a 1998. Dakar: Population Council.

Solo, Julie et al. 1999. Creating linkages between incomplete abortion treatment and family planning services in Kenya. Studies in Family Planning 30(1): 17-27.

Vernon, R., Foreit, J. 1999. How to Help Clients Obtain More Preventative Reproductive Health Care. International Family Planning Perspectives 25(4): 200-202. 
Vernon, R. et al. 2005. Systematic screening as a strategy to increase services integration in Honduras, FRONTIERS Final Report. Washington DC: Population Council.

Wender, RC. 1993. Cancer screening and prevention in primary care. Cancer 72: 1093-1099. 


\section{Appendix}

\begin{tabular}{|c|c|c|c|c|}
\hline \multicolumn{4}{|c|}{ To be filled in by Screener } & \multirow{2}{*}{$\begin{array}{l}\text { To be filled in } \\
\text { by Provider } \\
\text { OUTCOME }\end{array}$} \\
\hline & $\begin{array}{l}\text { CREENING QUESTIONS } \\
\text { Be sure to include reason } \\
\text { isit in required services. }\end{array}$ & FOLLOW-UP QUESTIONS & $\begin{array}{l}\text { DISCUSS AND } \\
\text { CIRCLE } \\
\text { REQUESTED } \\
\text { SERVICE(S) }\end{array}$ & \\
\hline \multicolumn{2}{|c|}{$\begin{array}{l}\text { What are the reasons for today's } \\
\text { visit? }\end{array}$} & \multicolumn{2}{|l|}{ Reasons for the visit: } & $\begin{array}{l}\text { 1. Provided } \\
\text { 2. Scheduled } \\
\text { 3. Referred }\end{array}$ \\
\hline 1 & $\begin{array}{l}\text { Are you pregnant? } \\
\text { 1. Yes } \rightarrow \\
\text { 2. No: go to \# } 2\end{array}$ & $\begin{array}{l}\text { Are you attending a prenatal } \\
\text { clinic? } \\
\text { 1. No } \rightarrow \\
\text { 2. Yes: go to \# } 3\end{array}$ & $\begin{array}{l}\text { PRENATAL } \\
\text { CARE }\end{array}$ & $\begin{array}{l}\text { 1. Provided } \\
\text { 2. Scheduled } \\
\text { 3. Referred }\end{array}$ \\
\hline 2 & $\begin{array}{l}\text { Are you trying to get } \\
\text { pregnant? } \\
\text { 1. No } \rightarrow \\
\text { 2. Yes: go to \# } 3\end{array}$ & $\begin{array}{l}\text { Are you using a contraceptive } \\
\text { method? } \\
\text { 1. No } \rightarrow \\
\text { 2. Yes: go to \# } 3\end{array}$ & $\begin{array}{c}\text { FAMILY } \\
\text { PLANNING }\end{array}$ & $\begin{array}{l}\text { 1. Provided } \\
\text { 2. Scheduled } \\
\text { 3. Referred }\end{array}$ \\
\hline 3 & $\begin{array}{l}\text { Do you have any children } \\
\text { under } 5 \text { ? } \\
\text { 1. Yes } \rightarrow \\
\text { 2. No: go to \# } 5\end{array}$ & $\begin{array}{l}\text { Are you taking them in for healthy } \\
\text { child control and growth } \\
\text { monitoring? } \\
\text { 1. No } \rightarrow \\
\text { 2. Yes: go to \# } 4\end{array}$ & $\begin{array}{l}\text { GROWTH AND } \\
\text { DEVELOPMENT }\end{array}$ & $\begin{array}{l}\text { 1. Provided } \\
\text { 2. Scheduled } \\
\text { 3. Referred }\end{array}$ \\
\hline 4 & $\begin{array}{l}\text { Have all your children under } \\
5 \text { been completely } \\
\text { vaccinated? } \\
\text { 1. No/DK } \rightarrow \\
\text { 2. Yes: go to \# } 5\end{array}$ & $\begin{array}{l}\text { Would you like to have your } \\
\text { child(ren) vaccinated? } \\
\text { 1. Yes } \rightarrow \\
\text { 2. No: go to \# } 5\end{array}$ & VACCINATION & $\begin{array}{l}\text { 1. Provided } \\
\text { 2. Scheduled } \\
\text { 3. Referred }\end{array}$ \\
\hline
\end{tabular}

